\title{
A one-sided coin: A critical analysis of the legal accounts of the Cypriot conflicts Nasia Hadjigeorgiou
}

\section{Introduction}

This chapter seeks to compare and contrast the series of legal cases that were launched by the Republic of Cyprus (hereafter, Republic or RoC), both in domestic and international courts, in response to the coup d'état and the Turkish military invasion of 1974. An analysis of this case law suggests that the RoC reacted to the two events in very different ways: while the response to the coup was sporadic and disorganised, the legal action taken against Turkey concerning the consequences of the invasion was well-planned and executed. Additionally, the ways in which the cases have been subsequently used by the state in order to shape the popular narrative concerning the two historical events also differ. ${ }^{1}$ The tendency discussed here - to use the law in order to provide greater or lesser authority to historical claims - is not unique to Cyprus. ${ }^{2}$ However, the close temporal proximity between the two events in question, both taking place in 1974, and the strikingly different responses to them by the state make for a particularly interesting comparison. The contrast between these varied state reactions offers a partial explanation for why the two events are remembered so differently by the Greek Cypriot (henceforth, GC) public: barely in the case of the coup and vividly in that of the invasion.

\section{A varied remembrance of the Cypriot conflicts}

On 15 July 1974 a GC paramilitary organisation staged a violent coup d'état against the legitimately elected and very popular - President of the RoC. Since the objective of the coup was to unite Cyprus with Greece, which was at the time a right-wing military dictatorship, the main victims of the violence were Turkish Cypriots and leftist GC. During the week that followed, the President, who had escaped and was being harboured abroad, was replaced by Nikolaos Sampson, the owner of a virulent nationalist newspaper and a puppet of the Greek junta government (ICG, 2008, p. 1). Sampson's supporters responded violently against anyone opposing the new regime, enforced military curfews on the entire population and prevented the publication of oppositional newspapers (Liasi, 1975, p. 564). This illegitimate, and largely unpopular, government collapsed 8 days later when Turkey, claiming that the coup posed a threat to the survival of the Turkish Cypriot minority, militarily invaded the island (Negatigil, 1989). As a result of the Turkish invasion, approximately 165,000 GC have been displaced (Global IDP Databse, 2003, p. 6), almost 1,500 went missing ${ }^{3}$ and thousands were killed. Since 1974, Turkey has military, political and economic control over the north of the island, with the RoC exercising effective control only in the south (Loizidou, 1997, para. 56).

These twin events - the coup and the military invasion that followed immediately after - are recalled in vastly different ways by the GC population, with the remembrance of the former being overshadowed by that of the latter. Debates about the comprehensive settlement of the 'Cyprus problem', the short-hand name given to the invasion and ongoing occupation of the island by Turkey, dominate everyday discussions both between politicians and lay people (Christophorou et al., 2010, p. 4). These discussions, among GC at least, almost always start from the premise that Turkey has illegally invaded Cyprus and that a solution to the Cyprus 
problem should address and respond to this (Lordos et al., 2009, p. 31). Moreover, the state has taken extensive action to remedy victims of the invasion and public events are often organised, either in commemoration of the dead or in remembrance of that day. ${ }^{4}$ The invasion is a key theme of the educational curriculum and pictures of the occupied territories appear on the front page of all textbooks, together with the slogan 'I don't forget' (Zembylas et al., 2016). Conversely, there is little, if any, discussion about the coup, with the official state policy being one of forgiving and forgetting. ${ }^{5}$ Part of the reason for these very different ways of remembering the two events of 1974 is the contrast between the short duration of the coup, with the legitimate government returning to power within days after its violent overthrow, and the long-term effects of the invasion, which are still experienced by GC today. Not only are the consequences of the invasion more long-term than those of the coup, but they are also more extensive. Although these are not wholly accurate, ${ }^{6}$ according to official statistics, 19 people died during the coup (Cassia, 2005, p. 73) and 5,000-6,000 during the invasion (Cassia, 2005, p. 52).

However, an additional explanation for this one-sided remembrance concerns the way in which the RoC has used the law to sanction history by projecting the public's memories of the invasion, while downplaying those of the coup. In particular, the state has influenced the way each of the two events is remembered, first, by responding to them through different legal procedures and second, by using the outcomes of these procedures in varying ways. On the one hand, it has punished the putschists's actions by criminally prosecuting their leader and launching an administrative process that resulted in the (temporary) purging of 62 individuals from the civil service. On the other, it has been condemning the effects of the invasion by resorting to a number of international bodies, most notably the European Court of Human Rights (henceforth, ECtHR). ${ }^{7}$ The RoC's administrative and legal responses to the coup and the invasion - and the effect these have had on the remembrance of each by the GC public - are discussed in section 3 of this chapter.

Instead, the remainder of this section focuses on the varying ways in which the state has used these legal and administrative decisions in order to shape how the twin events of 1974 are remembered. Most notably, the state has disseminated through a wide range of mediums, such as school textbooks, the decisions of international bodies that condemn the consequences of the invasion (see, for instance, Pantelidou and Hadjicosti, 1992, p. 303). The most overt example of this is a section on the website of the RoC Ministry of Foreign Affairs entitled 'The Cyprus Question'. ${ }^{8}$ This section extensively refers to two ECtHR cases, 'the well-known case of Titina Loizidou', and Cyprus v. Turkey, 'a case that proved to be of great importance for the people of Cyprus and their struggle for the just solution of the Cyprus problem.' The ECtHR's legal findings in these cases are presented as authoritative pieces of evidence for all the allegations made against Turkey and as proof of the fact that the invasion was an illegal action under international law. Similarly, GC politicians often use ECtHR judgments and UN resolutions as evidence of Turkey's illegal presence in Cyprus before proceeding to argue that any solution to the Cyprus problem should undo the injustices caused by the invasion and comply with international law (UN Secretary-General, 2003, para. 22).

The effects of seminal ECtHR judgments on GC's perception of history have not been researched in much detail; nevertheless, their impact on GC society as a whole is palpable. The importance that the state has attached to these legal cases has resulted in the general population being fairly familiar with the Court's main findings, especially in the case of Loizidou v. Turkey (Zembylas et al., 2016, p. 26). References to this 1995 judgment were 
made in the media even as late as 2014 (Hazou, 2014) and public events have been organised in honour of Mrs Loizidou. ${ }^{9}$ Ultimately, the Loizidou judgment, which is discussed in more detail in section 3, has become part of the GC's struggle against the Turkish invasion and occupation and a source of pride for them. This is confirmed by the fact that at one point approximately 1,400 cases with identical facts to, and having been inspired by, Loizidou had been launched by individual GC applicants to the ECtHR (Xenides-Arestis, 2007, para. 38).

Conversely, the use of Court cases or administrative decisions, either directly by the state or indirectly by other stakeholders, such as the media, to bolster the public's remembrance of the coup has been non-existent. Sampson's criminal prosecution and the administrative purge of the 62 putschists have received very little mention in legal textbooks and are only rarely considered in history textbooks or the popular literature (see, for example, Melides, 2010). The coup is almost never discussed in public affairs and even its anniversary tends to be overshadowed by commemorations of the Turkish invasion. Moreover, the website of the Ministry of Foreign Affairs, which so extensively discussed the case law relating to the invasion and occupation, makes no reference at all to the coup in its 46-page review of Cyprus' modern history. Unlike the invasion which has resulted in the unanimous condemnation by all Greek Cypriot political parties, they - and the media that supports them (Papadakis, 2003, p. 256) - have been divided as to how they should respond to the coup. On the one hand, right-wind parties, which advocate a strategy of amnesia in relation to the coup (President of the Republic, 1991), only organise commemorations of the invasion and view the coup as a largely insignificant pretext that Turkey used in order to implement her already existing plan to invade the island (Papadakis, 2003). On the other, left-wing parties argue that the coup and the invasion are inherently connected and press for the remembrance and commemoration of the coup's victims. Nevertheless, even the communist party, whilst eager to blame the right for the coup, rarely mentions the legal proceedings against the putschists due to concerns that these will provide support to Turkey's claim that its military invasion of Cyprus was a legitimate way of protecting Turkish Cypriots from the violence that had erupted on the island (Cassia, 2005, p. 73).

\section{Writing history by using the law}

Over the years, several ECtHR cases against Turkey have condemned the human rights violations that took place on the island as a result of the invasion and ongoing occupation. ${ }^{10}$ The leading ECtHR case on this issue is Cyprus v. Turkey, in which the former successfully argued that the consequences of the latter's invasion (among others, mass displacement and the continuing lack of access to information about the fate of missing persons) constituted violations of human rights. Importantly, this inter-state application to the Court from Cyprus against Turkey was in fact, not the first, but the fourth attempt to use the European human rights mechanisms in order to showcase the effects of the Turkish invasion. The first three applications were made, for procedural reasons, not to the European Court, but to the European Commission of Human Rights instead. While the Commission had decided in favour of Cyprus, its decisions - unlike those of the Court - were not legally binding. The fourth inter-state application therefore, was a strategic and well-calculated decision on behalf of the government to invest further state resources and risk a negative outcome in the Court in order to express in an even more authoritative forum its grievances against Turkey. This is evidence of the RoC's belief that a favourable judicial pronouncement could further legitimise its historical claims. 
The ECtHR is not the only international forum that Cyprus has approached in order to confirm the illegality of the Turkish invasion and its aftermath. There are also UN General Assembly resolutions urging the withdrawal of all foreign armed forces from Cyprus, ${ }^{11} \mathrm{UN}$ Security Council resolutions condemning Turkey's recognition of the 'Turkish Republic of Northern Cyprus ${ }^{12}$ and recommendations of the Parliamentary Committee of the Council of Europe expressing concern about the transfer of Turkish settlers in the north of Cyprus (Parliamentary Assembly, 2003). These resolutions, lobbied for by RoC officials, confirm the existence of a consistent belief among GC policy makers that pronouncements by international organisations are an effective way of recording the consequences of the military invasion and ongoing occupation and establishing an official narrative. The state's use of the law to make its historical claims even more authoritative is further illustrated by the decision of the Republic to become involved as an intervening party in cases brought to the ECtHR against Turkey by individual applicants. The most well-known individual application is Loizidou v. Turkey, in which the ECtHR held for the first time that the continuing prohibition of the applicant by Turkish troops to access her property in the occupied part of Cyprus resulted in a violation of her right to property (Loizidou, 1997).

Both in Loizidou and Cyprus v. Turkey, the applicants faced formidable procedural hurdles in convincing the ECtHR to hear their complaints. For instance, it was necessary to respond to Turkey's argument that it could only be responsible for human rights violations that took place within its own territory. Since in these cases the alleged violations took place in Cyprus, Turkey submitted that either the RoC or the unrecognised 'Turkish Republic of Northern Cyprus' should remedy them (Cyprus, 2002, para. 69). Moreover, the applicants' lawyers had to address Turkey's argument that it could not be liable for alleged violations that took place in 1974, since the Court only had jurisdiction to hear cases against it for events that occurred from 1990 onwards (Loizidou, 1997, para. 41). The RoC, directly in the inter-state case and as an intervening party in Loizidou, successfully responded to both of these procedural hurdles and broke new legal ground in the process. The complexity of the legal arguments made in the two cases, together with the immense amount of information that had to be gathered in order to prove the substantive allegations, illustrate the professionalism and commitment with which the state approached the exercise of recording the history of the invasion in a court of law.

Like the invasion, the government's response to the coup has been to turn to the law. Thus, in 1977, the executive prosecuted and the judiciary eventually convicted Nikolaos Sampson, the man who replaced the legitimate President during the 8-day duration of the coup (Sampson, 1977). On the one hand, Sampson's punishment and the Supreme Court's declaration that the actions of the illegitimate government had no legal effect, could be seen as an effective response to the coup by the state, comparable to the RoC's submissions in the ECtHR cases. On the other, the decision to prosecute just a single individual, implicitly sent the message that there was no one else to blame for the coup. By punishing only Sampson, other GC, who either knew about or supported the coup, were exonerated (Karstedt, 2009, p. 1). ${ }^{13}$ An additional problem with this prosecution concerns the historical fact, which was discussed by the Supreme Court in the case itself, that while Sampson was involved in the coup, he was not the mastermind behind it. ${ }^{14}$ This consideration is arguably reflected in the fact that Sampson only served approximately six years out of his 20 -year sentence (Lewis, 2001). The ambivalence of the state through its judicial and executive branches to punish Sampson is reflected today in the public's perception of his person. While some GC remember and condemn his actions and those of the organisation he represented, most have either simply forgotten about him or excuse his activities by portraying him as a misguided puppet of the 
Greek junta government. Most problematic, is the small but vocal part of GC society which views Sampson as an unsung national hero. The existence of such views among the public can partly be attributed to the state's reluctance to condemn in the clearest terms the organised attack against it sovereignty.

This reluctance is also reflected in the lukewarm stance the state adopted against 62 identified putschists. Originally the government had reacted to the coup by passing a series of laws that were intended to identify, investigate and put on trial those who had actively contributed to it. ${ }^{15}$ However, due to significant delays in their implementation, which themselves point to the state's reluctance to punish the perpetrators, an additional law was passed which empowered the executive through the Council of Ministers to terminate the employment of civil servants who were believed to have been actively involved in the coup. ${ }^{16}$ Using this law, and relying on an administrative process (instead of a trial) that suffered from significant procedural limitations, the Council dismissed 62 civil servants (Anastasiades, 1988). It is not clear what evidence the Council relied on in order to identify the 62 and whether there were others in the civil service who were also involved in the coup. Moreover, since the law empowered the Council to dismiss only civil servants, no action was taken against putschists who were working in the private sector. Most problematically, the 62 were not put on trial and were not given the opportunity to present evidence to the Council of Ministers in their defence. Despite these serious deficiencies, the Supreme Court ruled in Christodoulides (1983) that the Council of Ministers' decision to terminate the services of the 62 was done for public interest reasons, rather than in order to punish them. Since the dismissals were not the results of disciplinary proceedings, the Court was able to gloss over the lack of procedural safeguards and argue that it was not necessary to comply with these in the first place.

The RoC's decision to empower the Council of Ministers, rather than the judiciary, to punish the putschists resulted in three problems, which directly affected the way in which the coup is remembered by the GC public. The first problem was that the administrative process followed by the Council, which fell far below any fair trial requirements, made it necessary to label the dismissals as public interest decisions. While this served as a useful shortcut since it allowed the government to act quickly, it failed to send the message that the putschists' actions were deplorable and in need of punishment. In fact, one could argue that since the very premise of the Court's decision was that the dismissals were not the result of disciplinary proceedings, the 62 had done nothing wrong or worth disciplining. As a result, this could be perceived as a message from the state that the actions of the putschists were not blameworthy enough to deserve the censure of the law through criminal proceedings. The second immediate problem with the decision was that failing to rely on normal criminal proceedings was to the detriment of individual justice for the 62. In turn, this made it both possible and plausible for them to argue that the government was so determined to punish someone for the coup that it scapegoated them in the process. In the end, the lack of transparency that characterised the Council's proceedings made it difficult to determine whether such allegations were true or not and clouded the contribution they could have made to an accurate historical account of what happened and who was to blame for the coup. ${ }^{17}$ Scapegoating defendants is a danger that exists whenever alleged perpetrators are punished for a historical wrong, but it is particularly serious when minimum fair trial requirements have not been met (Buruma, 1995, p. 142; Koskienniemi, 2002). ${ }^{18}$

The third problem with the state's decision to rely on administrative, rather than judicial procedures, was that it encouraged a range of ill-suited government bodies to take justice in their own hands. Illustrative of this are the decisions of the Educational Service Committee 
(Mylonas, 1982) and a local Bar Commission (In re X Y, 1981) to discipline respectively a headteacher and a lawyer who had been allegedly involved in the coup. The state's decision to rely on an administrative process, which was by its nature less likely to capture the public's attention than a high profile legal case, undermined from the very start the objective of sending a message of condemnation against the coup. However, this became even harder to achieve when obscure bodies like a Bar Commission, the very existence of which is often unknown to the general public, took the unilateral initiative of punishing the putschists. Moreover, since it was never these bodies' job to punish their members for such offences, they lacked the appropriate procedural safeguards to hear the allegations, which in turn, undermined the legitimacy of their decisions and made their findings vulnerable to attack. Thus, the method that the state decided to use when responding to the coup - namely, relying on an administrative rather than a judicial process, which had an ad hoc, untransparent and decentralized nature - directly affected how this historical event has been recalled by the GC population at large.

Less than 10 years after Christodoulides, the case that confirmed the constitutionality of the Council of Ministers' decision to dismiss the putschists, a differently composed Council of Ministers revoked the dismissals of the 62 and asked them to return to their positions in the civil service. ${ }^{19}$ In response, a month later, the House of Representatives passed a law which annulled the new Council of Ministers decision and amended the state budget in order to prevent the payment of the 62's salaries. This law was challenged in President of the Republic v. House of Representatives in which the majority of a divided court held, contrary to Christodoulides, that the law preventing the 62 to return to their posts was unconstitutional. Thus, even as late as 1994, and in stark contrast to the unanimously supported efforts that were simultaneously taking place at the ECtHR in relation to the Turkish invasion, the political and legal elite of the country remained divided in its response to the coup. As a result, the only clear message sent to the public was that the state was unwilling to unequivocally condemn the illegal acts of the putschists and punish them in a paradigmatic and meaningful way.

\section{The reasons behind the selective amnesia}

At least to some extent, the varied remembrance of the historical wrongs of 1974 among the GC community is state-sanctioned: it has been caused, both by the different legal treatment the two have received and by the way the legal sources relating to each have been used by state organs and broader society since then. The reason the state has taken an interest in shaping the way these historical events are remembered is because this suits its two main political objectives. First, it is in the RoC's interests to preserve and build unity among its population. The ambivalence in the state's response to the coup, stems from a legitimate disagreement between the political parties as to whether this objective is best addressed by forgetting about the divisive coup and moving on or by directly acknowledging and addressing the harm that has been done to the coup's victims. ${ }^{20}$ Conversely, the ECtHR case law against Turkey has received so much attention and support because the political parties agree that one of the best ways to unite the GC public is by creating a common external enemy. Second, since the Republic's objective is to negotiate a settlement to the Cyprus problem that undoes the effects of the Turkish invasion as much as possible, it is in its interests to present $\mathrm{GC}$ as being exclusively the victims of belligerent actions. ${ }^{21} \mathrm{An}$ acceptance of this narrative makes it easier to argue that the international community should push Turkey to adopt a more compromising stance on the negotiating table. The RoC has 
projected the ECtHR case law to such an extent precisely because it contributes to the building of this narrative (Christophorou, 2010, p. 64 and 83). Conversely, since the administrative and judicial decisions concerning the coup paint a more nuanced picture, with some GC being both victims and perpetrators of actions that took place in 1974, it has been in the interests of the state to ignore them.

At the same time however, it is also conceivable that factors that were beyond the state's control have also affected the extent and way in which the legal cases and the events relating to them are remembered. One such factor concerns the fact that the invasion cases were litigated at the ECtHR, while the coup was addressed by the Cypriot judiciary and administrative bodies. ${ }^{22}$ This difference between the organs dealing with the two events has influenced the way each is remembered in two ways. On the one hand, the international presence of the ECtHR has given its decisions greater legitimacy and visibility than those of the Supreme Court. Both Loizidou and Cyprus v. Turkey were heard and decided by the Grand Chamber of the European Court. The success of the applicants to convince this international and impartial group of judges, rather than any domestic decision-maker, that Turkey was responsible for human rights violations in Cyprus added legitimacy and persuasiveness to their complaints. Moreover, the fact that this decision was delivered in Strasbourg and was communicated, through the different mechanisms of the Council of Europe, to all the member states of the organisation, gave it a lot more visibility than any domestic judgment could have received. Conversely, Sampson's prosecution was a much more discrete state of affairs and the punishment of the 62 putschists through administrative action even more quiet still. As Mark Osiel (1995-1996, p. 505) argues, in order for a legal case to make history, the hearings must capture the public's attention. Arguably, it was much easier to achieve this through the prominent stage provided by the ECtHR, rather than in the more humble setting of the domestic courts and administrative organs.

On the other hand, the different rules of procedure in domestic and international bodies have determined who can be brought to justice as the alleged wrongdoer in each case. Since the ECtHR is an international court, the respondent to any allegations of wrongdoing had to be the state of Turkey itself. Conversely, dealing with the coup through Cyprus' criminal and administrative law systems meant that only individual defendants could be brought to justice. Thus, the litigation of the two events in different courts sent varying messages about the status of the perpetrator and the seriousness of the wrongdoing in each case: since the respondent in the ECtHR cases was the state, the invasion and its consequences were understood as the responsibility of Turkey and were therefore more easily perceived as a well-coordinated and deliberate attack from one country against another. Opposing this, by only prosecuting Sampson, it became possible to present the coup as an instance of one person breaking the law, rather than as another orchestrated threat to the sovereignty of the Republic. In turn, the collectivisation of the blame in the case of the invasion and its individualisation in that of the coup, affected the seriousness of each crime in the eyes of the people and the way in which they remember it (Osiel, 2014).

\section{Conclusion}

The two sets of legal responses that have been explored here are not always easy to compare: the cases concerning the invasion were litigated in an international court during the 1990s and 2000s, while those dealing with the coup were the outcomes of domestic bodies in the 1970s until the 1990s. Yet, the attitudes of the GC political elite that the two sets of cases 
reflect have been consistent over the years: while RoC representatives have been shouting loudly and clearly (both during and after the adjudication of the cases) that the Turkish invasion is an illegal foreign attack on Cyprus, they have been mostly silent about the attack to the government that came from within. It is partly as a result of this, that the GC public is suffering from a type of selective amnesia about one of the two historical wrongs of 1974.

The purpose of this chapter has not been to criticise the RoC's attempts to condemn the invasion by applying to the ECtHR. Despite limitations in the process, it has also not been the intention to criticise the Republic's response to the coup. Especially the latter needs to be seen in light of the context that prevailed at the time, with GC being deeply divided among themselves and in urgent need to rebuild their country following the catastrophic Turkish invasion. Rather, the objective of this chapter has been to illustrate that decisions of the government to use the law in a particular way can significantly affect how given historical events are remembered by the population at large. Whether a historical event is subject to a judicial or administrative process and whether that takes place on the international or domestic plane can have a sizable impact on the establishment of a well-remembered official narrative. At the same time, it is necessary to acknowledge that it is not only the legal or administrative processes that are important, but also how these are subsequently utilized by the different stakeholders.

\section{References}

Associated Press. 2014. Cypriots Mark 40 ${ }^{\text {th }}$ Anniversary of Invasion. http://www.dailymail.co.uk/wires/ap/article-2698968/Cypriots-mark-40th-anniversaryinvasion.html. Accessed 05 April 2016.

Attorney-General of the Government of Israel v. Eichmann (Israel Supreme Court 1962), Intinternational Law Reports 36: 277.

Baruch, Marc Olivier. 2014. Changing things so everything stays the same: The impossible "épuration" of French society, 1945-2000. In Transitional justice and memory in Europe (1945-2013), ed. Nico Wouters, 63-93. Cambridge: Intersentia.

Brems, Eva and Laurens Lavrysen. 2013. Procedural justice in human rights adjudication: The European Court of Human Rights. Human Rights Quarterly 35: 176-200.

Buruma, Ian. 1995. The wages of guilt: Memories of war in Germany and Japan. London: Vintage.

Cassia, Paul Sant. (2005) Bodies of evidence: Burial, memory and the recovery of missing persons in Cyprus. New York: Berghahn Books.

Christodoulides and others v. The Republic of Cyprus, through the Council of Ministers (1983) 3 CLR 1297.

Christophorou, Christophoros, Sanem Sahin, and Synthia Pavlou. 2010. Media narratives, politics and the Cyprus problem. Nicosia: Peace Research Institute Oslo.

Cyprus v. Turkey (2002) 35 E.H.R.R. 30.

Global IDP Database. 2003. Profile of internal displacement: Cyprus. Geneva: Norwegian Refugee Council.

Hazou, Elias. 2014. ECHR ruling unprecedented. Cyprus Mail: Nicosia, 14 May. http://cyprus-mail.com/2014/05/14/echr-ruling-unprecedented/. Accessed 31 March 2016.

In re X Y an Advocate (1981) 1 CLR 401.

International Crisis Group (ICG). 2008. Cyprus: Reversing the drift to partition. Nicosia/Istanbul/Brussels: International Crisis Group.

Karstedt, Susanne. 2009. Introduction: The legacy of Maurice Halbwach. In Legal 
institutions and collective memories, ed. Susanne Karstedt, 1-26. Oxford: Hart Publishing.

Koskienniemi, Martti. 2002. Between impunity and show trials. Max Planck Yearbook of United Nations Law 6: 1-35.

Lewis, Paul. (2001). Nikos Sampson, 66, Cyprus President after coup, dies. New York Times, 11 May.

Liasi and others v. Attorney General of the Republic (1975) 3 CLR 558.

Loizidou v. Turkey (1997) 23 E.H.R.R. 513.

Lordos, Alexandros, Erol Kaymak, and Nathalie Tocci. 2009. A people's peace in Cyprus: Testing public opinion on the options for a comprehensive settlement. Brussels: Centre for European Policy Studies.

McEvoy, Kieran and Louise Mallinder. 2012. Amnesties in transition: Punishment, restoration and the governance of mercy. Journal of Law and Society 39: 410-440.

Melides, Christos. 2010. Constitutional Law. In Neocleous' introduction to Cyprus Law, ed. Andreas Neocleous $3^{\text {rd }}$ edn., 87-117. Cyprus: Neocleous Publishing.

Michael, Michális Stavrou. 2009. Resolving the Cyprus conflict: Negotiating history. New York: Palgrave Macmillan.

Mylonas v. The Educational Service Committee (1982) 3 CLR 880.

Negatigil, Zaim. 1989. The Cyprus question and the Turkish position in international law. Oxford: Oxford University Press.

Osiel, Mark J. 1995-1996. Ever again: Legal remembrance of administrative massacre. University of Pennsylvania Law Review 144: 463-704.

Osiel, Mark J. 2014. Who are atrocity's "real" perpetrators, who its "true" victims and beneficiaries?. Ethics and International Affairs 28: 281-297.

Pantelidou, Angeliki and Constantia Hadjicosti. 1992. History of Cyprus: Medieval to modern (1192-1974). Nicosia: Ministry of Education.

Papadakis, Yiannis. 2003. Nation, narrative and commemoration: Political ritual in divided Cyprus. History and Anthropology 13: 253-270

Parliamentary Assembly. 1996. Measures to dismantle the heritage of former communist totalitarian systems. Resolution 1096. Strasbourg: Council of Europe.

Parliamentary Assembly. 2003. Colonisation by Turkish settlers of the occupied part of Cyprus. Recommendation 1608. Strasbourg: Council of Europe.

President of the Republic v. House of Representatives (1991) 3 CLR 252 [in Greek].

President of the Republic v. House of Representatives (No. 4) (1994) 3 CLR 157 [in Greek].

Republic of Cyprus, through the Council of Ministers v. Andreas Anastasiades and Others (1988) 3 CLR 633.

Republic v. Nicolaos Sampson (1977) 2 C.L.R. 1.

Rolf Gustafson v. Sweden (1997) 25 E.H.R.R. 623.

UN Secretary-General. 2003. Report of the Secretary-General on his mission of good offices in Cyprus. New York: UN.

Xenides-Arestis v. Turkey (2007) 44 E.H.R.R. SE13.

Zembylas Michalinos et al. 2016. Human rights and the ethno - Nationalist problematic through the eyes of Greek-Cypriot teachers. Education, Citizenship and Social Justice 11: 1933.

\footnotetext{
${ }^{1}$ In this chapter, the word 'case' always refers to legal cases.

${ }^{2}$ Similar attempts to use the law in order to establish an authoritative historical record took place for example, in Israel (Eichmann, 1962).
} 
${ }^{3}$ Committee on Missing Persons in Cyprus, 'Figures and Statistics of Missing Persons up to 29 March 2016', available at http://www.cmp-cyprus.org/media/attachments/Quick\%20Statistics/Facts and Figures 29-32016.pdf, accessed 05 April 2016.

${ }^{4}$ See, for example, the commemorations that took place for the $40^{\text {th }}$ anniversary of the Turkish invasion (Associated Press, 2014).

${ }^{5}$ This policy was first introduced with the speech delivered by President Makarios, immediately after the coup, when he declared that 'it is not my intention to [...] bring to justice those [...] who took part in the coup against me. I [...] grant them amnesty in the hope that the desired concord and unity among our people will come about.' (speech cited in Sampson, 1977).

${ }^{6}$ Victims' family members have often (successfully) argued that their relatives were killed during the Turkish invasion and not the coup; this is because family members of those who died during the invasion receive economic benefits and public recognition that are not shared by the relatives of those who died during the coup (Cassia, 2005, p. 73).

${ }^{7}$ The reason the RoC has focused on the illegality of the effects of the invasion, rather than that of the invasion itself was because the ECtHR does not have jurisdiction to hear cases against Turkey, whose events took place in 1974.

${ }^{8}$ Ministry of Foreign Affairs of the Republic of Cyprus, 'The Cyprus Question', available at http://www.mfa.gov.cy/mfa/mfa2006.nsf/cyprus01 en/cyprus01 en?OpenDocument, accessed 31 March 2016. Similar information is also offered on the website of the RoC Press and Information Office, available at http://www.moi.gov.cy/MOI/pio/pio.nsf/a problem en/a problem en?OpenDocument, accessed 31 March 2016.

9 'Titina Loizidou: The people behind the cases' (Event at the University of Cyprus, 14 October 2015).

${ }^{10}$ See note 7 above.

${ }^{11}$ UN General Assembly Resolution 3212 (XXIX) (1 November 1974); UN General Assembly Resolution 'Question of Cyprus' A/RES 37/253 (16 May 1983).

${ }^{12}$ UN Security Council Resolution 550 (11 May 1984).

${ }^{13}$ It is unclear how many people were involved in the planning of the coup, but the purging of the 62 suggests that it was definitely more than a single individual.

${ }^{14}$ As the Court noted in the Sampson case, the masterminds behind the coup were generals of the Greek army, who were never brought to justice.

${ }^{15}$ Laws Concerning Some Disciplinary Offences (Conduction of Investigation and Trial) 1977 until 1978 (No. 3/77, 38/77 and 12/78) [in Greek].

${ }^{16}$ Law Concerning the Termination of Procedure Provided in Laws Concerning Some Disciplinary Offences (Conduction of Investigation and Trial) 1977 until 1978 (No. 57/78) [in Greek].

${ }^{17}$ Good practice suggests that where purging of civil servants will take place, 'the right of defence, the presumption of innocence until proven guilty, and the right to appeal to a court of law must be guaranteed.' (Parliamentary Assembly, 1996, para. 12)

${ }^{18}$ The obligation that a public body complies with fair trial requirements exists when that body affects an individual's civil rights and obligations and irrespective of whether this body is integrated within the standard judicial machinery of the country (Rolf Gustafson, 1997, para. 45). Even if these legal requirements do not apply to the Council of Ministers, there are good public policy reasons why such a body should nevertheless respect the rule of law (Brems and Lavrysen, 2013).

${ }^{19}$ This has been criticised by families of the coup's victims because it sends mixed signals about the culpability of the 62. It should be noted however, that the reinstatement of purged civil servants has also taken place in other European states, such as France in the 1950s, where immediate post-Second World War sanctions were softened. (Baruch, 2014, p. 76)

${ }^{20}$ This disagreement has been widely discussed in the literature. For an overview, see McEvoy and Mallinder (2012).

${ }^{21}$ In the negotiations for the Cyprus problem the RoC primarily represents the interests of the GC community, with the interests of the TC community being represented by Turkey and the TC leadership (Michael, 2009).

${ }^{22}$ Where each case was to be litigated (i.e. on the international or the domestic level) was termined by the existence of procedural rules, rather than the political objectives of the RoC. 